AGH DRILLING, OIL, GAS • Vol. 35 • No. $1 \cdot 2018$

http://dx.doi.org/10.7494/drill.2018.35.1.31

\author{
Jan Macuda*, Małgorzata Macuda**
}

\title{
DRILLING LARGE DIAMETER WATER WELLS IN CARBONATE STRATA IN THE LUBLIN AREA***
}

\section{INTRODUCTION}

In the predominant part of the Lublin area the main useful aquifer is associated with the Upper Cretaceous strata. They are represented by fissured marls, chalk, limestone and gaizes. In such rocks groundwater flows through fractures and various cracks. Water accumulation considerably varies in the top part of these formations and the difference of localization of the water level may exceed $20 \mathrm{~m}$ [8, 13]. In the Lublin Basin area the depth of deposition of rocks characterized by higher permeability (filtration coefficient $k>1 \cdot 10^{-5} \mathrm{~m} / \mathrm{s}$ ) is limited to $100 \mathrm{~m}$ in chalk and clayey marls, $120-140 \mathrm{~m}$ in marls and $150 \mathrm{~m}$ in gaizes and limestones. In the fault areas which accompany river valleys, the filtration coefficient of gaizes and limestones may even exceed $2 \cdot 10^{-3} \mathrm{~m} / \mathrm{s}, 9 \cdot 10^{-4} \mathrm{~m} / \mathrm{s}$ at a distance of about $500 \mathrm{~m}$ from the fault, and even less at bigger distance [9]. Figure 1 represents an exemplary lithostratigraphic profile of an intake realized in Mełgiew county.

Drilled wells of different design are used for opening this water level for communal and industrial use. Such wells are most frequently drilled with rotary method with right or inverse mud circulation with roller cone bits. No high penetration rates can be obtained due to the considerable share of carbonate hardly drillable rocks. This elongates the time of drilling wells and so the time of exposure of the near well zone of the aquifer to the negative impact of mud and lowering of hydraulic parameters of wells.

* AGH University of Science and Technology, Faculty of Drilling, Oil and Gas, Krakow, Poland

** Poznań University of Economics and Business, Poznań, Poland

*** Work performed within statutory research no. 11.11.190.555 of AGH UST and Poznań University of Economics and Business 
For the sake of improving the efficiency of water wells in carbonate rocks, drillability tests were performed for cogged bits to determine optimum mechanical parameters of drilling technology.

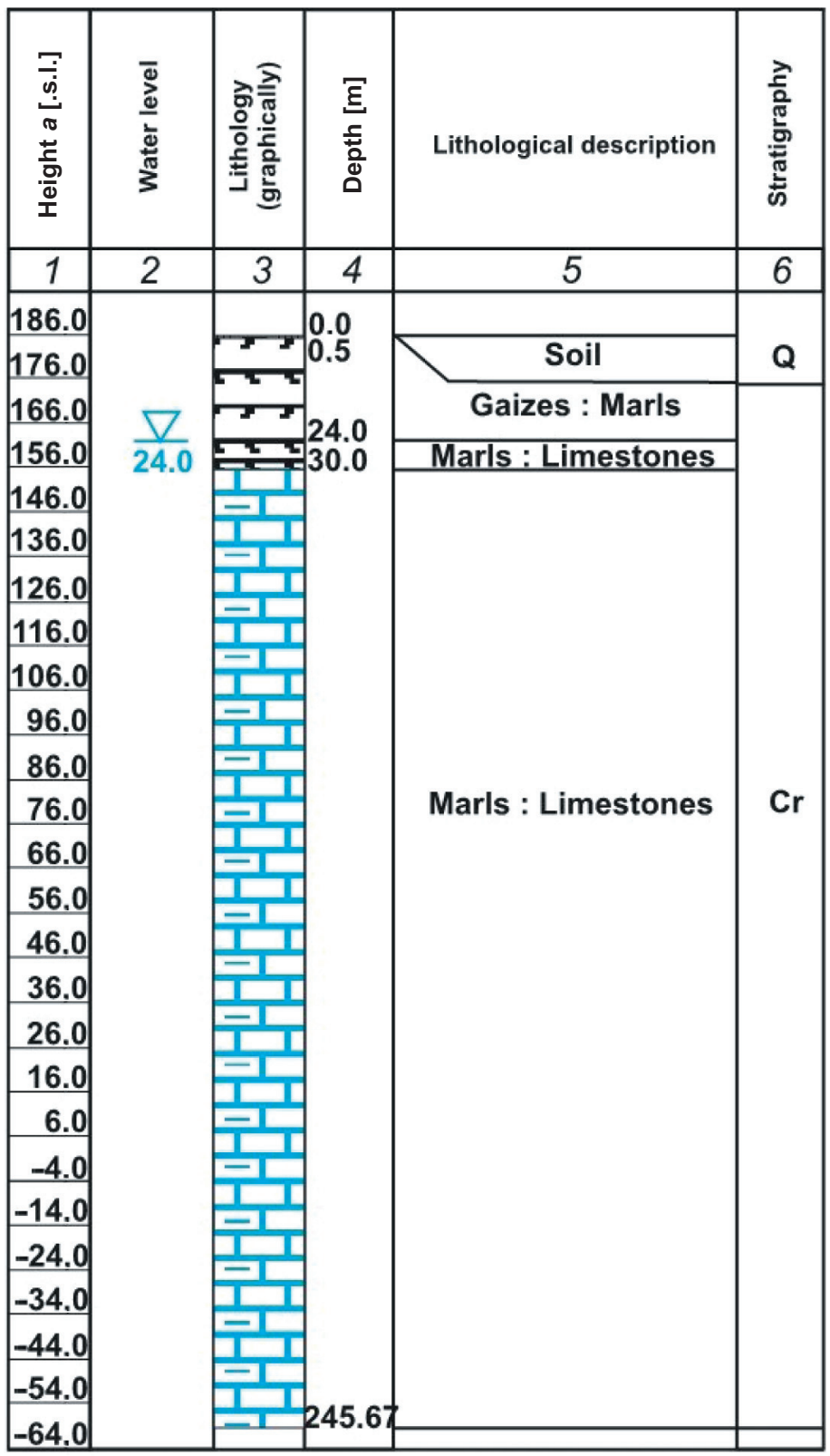

Fig. 1. Lithostratigraphic profile of water well in Janowice, Mełgiew county [12] 


\section{DESIGN OF LARGE DIAMETER WATER WELLS}

An water well should be properly designed and have a correctly adjusted filter thanks to which water from aquifers could enter inside of it without too much hydraulic head. It can be also equipped with a pump aggregate with demanded technological parameters.

The design of a large diameter well 80-150 m deep, realized with rotary method and mud, most frequently consists of two casing columns and a filter column. Each time the number of casing pipes depends on geological and hydrogeological conditions, assumed drilling method, type and scope drill tests and way in which water is produced from the well $[1,10,15]$. Moreover each water well should have well pit, which finishes off and protects the well against contamination and damaging. In these conditions the hardware can be correctly introduced to the well, i.e. valves, manometer, water meter, etc. The analysis of the influence of geological and hydrogeological materials on water wells realized in the Lublin district area in carbonate rocks revealed that normal and large diameter wells were drilled depending on the aquifer [12, 13]. The schematic of casing of water wells in carbonate strata in the Lublin district area is presented in Table 1.

Table 1

Casing schematics of water wells realized in Lublin area

\begin{tabular}{|c|c|c|c|c|}
\hline Type of well & $\begin{array}{l}\text { Design } \\
\text { variant }\end{array}$ & Type of column & $\begin{array}{c}\text { Bit diameter, } \\
D_{\dot{s}}[\mathrm{~m}]\end{array}$ & $\begin{array}{l}\text { Outer diameter } \\
\text { of column } \\
D_{z}[\mathrm{~m}]\end{array}$ \\
\hline \multirow{3}{*}{$\begin{array}{l}\text { Normal } \\
\text { diameter }\end{array}$} & I & $\begin{array}{l}\text { Surface } \\
\text { Filter }\end{array}$ & $\begin{array}{l}0.473 \\
0.374\end{array}$ & $\begin{array}{l}0.406 \\
0.195\end{array}$ \\
\hline & II & $\begin{array}{l}\text { Surface } \\
\text { Filter }\end{array}$ & $\begin{array}{l}0.508 \\
0.374\end{array}$ & $\begin{array}{c}0.406 \\
0.305 \text { or } 0.280\end{array}$ \\
\hline & III & $\begin{array}{l}\text { Surface } \\
\text { Conductor } \\
\text { Filter }\end{array}$ & $\begin{array}{l}0.560 \\
0.474 \\
0.374\end{array}$ & $\begin{array}{l}0.508 \\
0.406 \\
0.280\end{array}$ \\
\hline \multirow{2}{*}{$\begin{array}{l}\text { Large } \\
\text { diameter }\end{array}$} & I & $\begin{array}{l}\text { Surface } \\
\text { Filter }\end{array}$ & $\begin{array}{l}0.670 \\
0.560\end{array}$ & $\begin{array}{l}0.611 \\
0.406\end{array}$ \\
\hline & II & $\begin{array}{l}\text { Surface } \\
\text { Conductor } \\
\text { Filter }\end{array}$ & $\begin{array}{l}0.760 \\
0.670 \\
0.560\end{array}$ & $\begin{array}{l}0.711 \\
0.611 \\
0.406\end{array}$ \\
\hline
\end{tabular}

\section{GEOLOGICAL-DRILLING CONDITIONS OF DRILLING WATER WELLS}

A well $137 \mathrm{~m}$ deep was realized for the planned water production for communal purposes from carbonate formations. Quaternary material in the form of loess, clay, 
fine and powder sand as well as gravel and loam were found in the drilled lithological profile to the depth of $12.7 \mathrm{~m}$ from the surface. Carbonate beds (marls and limestones) are deposited directly underneath.

A two column well was drilled with a rig Wirth B3A with rotary method with reverse mud circulation and induced airlift. Initially the well $0.67 \mathrm{~m}$ in diameter was drilled a depth of $14 \mathrm{~m}$ for surface casing. Loose and or weakly compact strata were drilled with a cutter bit and the top of the compact rocks with a cogged bit. Then a casing column $\varnothing 0.611 \mathrm{~m}$ was driven to the well and cemented to the surface. Further drilling of the well was realized with a cogged bit $0.56 \mathrm{~m}$ in diameter.

Many water wells of similar design are drilled in this region by numerous drilling companies and they most frequently use one universal bit for drilling sections of the same diameter. The analysis of literature also reveals that each of the companies has its own experience in the selection of mechanical parameters of drilling technology [14]. Therefore in industrial conditions, when drilling diversified rock levels in the profile a drillability test should be made to optimize mechanical parameters of drilling.

\section{INFLUENCE OF PARAMETERS OF DRILLING TECHNOLOGY ON RATE OF PENETRATION}

The influence of properties of drilled rocks as well as mechanical and hydraulic parameters of drilling technology on technical indices of drilling of small and normal diameter wells was extensively described in works $[1,2,5,11,19]$. The analysis of literature revealed that when drilling at small depths the influence of bit wearing is statistically insignificant as far as the obtained drilling advancement is concerned and stays within the limits of statistical error. Moreover drilling shallow wells is conducted in cycles at short sections where the wearing does not have influence of the achieved technical and economic indices of drilling. Therefore in industrial conditions, when drilling large diameter wells with cutter and cogged bits, the best fit is reached for a model which does not account for wearing. The average rate of penetration is most frequently described with equations taking into account the drillability coefficient and effect of mechanical parameters of drilling technology, i.e. weight of bit and rotations of the bit $[6,10]$ :

$$
v_{o}=Z \cdot P^{a} \cdot n^{b}
$$

where:

$Z$ - drillability coefficient,

$P$ - weight of bit,

$n$ - rotational speed of bit,

$a$ - coefficient of influence of weight of bit on drilling rate,

$b$ - coefficient of influence of rotational speed of bit on drilling rate. 
Drillability coefficient $Z$ is always positive and describes the bit/rock system in the process of drilling. The higher is $Z$ value, the easier the rock can be drilled and the higher rate of penetration will be obtained. The effect of weight of bit and rotary speed of bit on the rate of penetration was best described in literature [10, 11]. Depending on the properties of drilled rocks the value of the power exponent $a$ changes from 0.6 to 2.3 and $b$ from 0.1 to 1.0

Hydraulic parameters of purging wellbore bottom also have a significant impact on the momentary rate of penetration $[18,20]$. The analyses revealed that the increase of mud density, solids content in mud, dispersion level and increase of kinematic viscosity result in the lowering of the rate of penetration. The rate of penetration increases with the growing filtration of mud.

\section{DRILLABILITY TESTS WITH COGGED BIT IN ROCKS}

For the sake of establishing optimum mechanical parameters of drilling of wells in carbonate rocks represented by marls and limestones, drillability tests were performed for the following assumptions:

- bit cycle in macroscopically homogeneous rocks,

- bit type correctly selected for the given type of drilled rock,

- weight on bit and its rotary speed have constant values,

- weight on bit and rotary speed belong to a set of admissible decisions, resulting from the technical characteristic of the rig.

For the sake of performing drillability tests in the drilled profile, there were separated macroscopically homogeneous layers of similar drillability for a definite kind and type of bit.

Two macroscopically homogeneous layers were identified in the Cretaceous carbonate profile based on literature [17]:

$$
\begin{aligned}
& \mathrm{W}_{1}-\text { marls, } \\
& \mathrm{W}_{2}-\text { limestones. }
\end{aligned}
$$

Prior to the drillability tests the limitations for mechanical parameters of drilling technology were established taking into account the technical characteristic of rig Wirth B3A and strength of the drill string and cogged bit:

$$
\begin{aligned}
& P \in\left(P_{\min } ; P_{\max }\right) \\
& n \in\left(n_{\text {min }} ; n_{\text {max }}\right)
\end{aligned}
$$

where:

$$
\begin{aligned}
& P_{\min }, P_{\max }-\text { lowest and highest values weight on bit, } \\
& n_{\min }, n_{\max }-\text { lowest and highest values of rotary speed of bit. }
\end{aligned}
$$


Five measuring points were established for the planned drillability tests $[6,10,15]$ at the assumed limitations (2) and (3), at which the specified wellbore sections were drilled. Each time the final point of the drillability test corresponded with the initial point. This was to verify whether or not the drilling was realized in the same macroscopically homogeneous layers. The well is assumed to be drilled in the same conditions if the rate of penetration at point 1 and 6 does not change by more than $10-15 \%$.

Drillability tests with a cogged bit $0.56 \mathrm{~m}$ in diameter were conducted for the following drilling technology parameters:

- weight of bit

- rotary speed of bit

- volumetric stream of drilling mud

- drilling mud flow rate inside drilling pipe

$$
\begin{array}{r}
1.96-4.90 \cdot 10^{4} \mathrm{~N}, \\
0.5-1.5 \mathrm{~s}^{-1}, \\
0.077 \mathrm{~m}^{3} / \mathrm{s}, \\
4.3 \mathrm{~m} / \mathrm{s} .
\end{array}
$$

Measurement sections of 0.3 and $0.5 \mathrm{~m}$ were selected to represent the planned thickness of the drilled layer. Each measurement section was drilled at constant rotary speed and axial thrust.

\section{RESULTS AND DISCUSSION}

For finding the dependence of mechanical rate of penetration on axial thrust and rotational speed of bit in selected layers $\mathrm{W}_{1}$ and $\mathrm{W}_{2}$, various regression models were analyzed [3, 4]. The most favorable results were obtained for the power model of the effect of axial thrust and rotational speed on the rate of penetration. The regression coefficient and statistical parameters proving very good fitting of the model to measurement data are presented in Tables 2 and 3. The average rate of penetration of a cogged bit $0.56 \mathrm{~m}$ in diameter is described with equation (1).

For analyzing power model of the effect of axial thrust and rotational speed of the bit, equation (1) was logarithmized on both sides to a linear equation:

$$
\ln V=\ln Z+a \cdot \ln P+b \cdot \ln n
$$

The regression coefficients for model (2) and their statistical significance was calculated with program STATISTICA - multiple regression module [7, 16].

The most important parameters describing good fitting of the model is the coefficient of determination $R^{2}$. This coefficient measures what part of general variability of dependent variable is explained by regression, and assumes values from 0 to 1 . The closer is $R^{2}$ to unity, the better is the fitting of the model. The analysis of values obtained for particular macroscopically homogeneous layers shows that the model is well fitted.

The corrected $R^{2}$, which determined the fitting of the regression equation to another sample from the same population is also given in the statistical analysis. Its value is 
always lower than $R^{2}$. The $\mathrm{F}$ statistic is also used to verify a hypothesis that regression coefficients are not equal to 0 . The estimation error of the model defines the difference between the constant value and the calculated one. Determined model coefficients of average rate of drilling $a, b$ and $\mathrm{Z}$ for selected macroscopically homogeneous layers $\mathrm{W}_{1}$ and $\mathrm{W}_{2}$ as well as parameters verifying the statistical correctness of the model are presented in Tables 2 and 3:

- sample size $M$,

- significance level $\alpha$,

- t-distribution for regression coefficient,

- critical value t-value $t_{k}$,

- multiple correlation coefficient $R$,

- critical multiple correlation coefficient $R_{k}$,

- Fisher-Snedecor test value F,

- critical value for Fisher-Snedecor test $\mathrm{F}_{k}$,

- residual error $B$.

\section{Table 2}

List of parameters appearing in equation for average mechanical rate of penetration with a cogged bit $0.56 \mathrm{~m}$ in diameter in layers $\mathrm{W}_{1}$

\begin{tabular}{|c|c|c|c|}
\hline Dependent parameter & $\begin{array}{l}\text { Regression } \\
\text { coefficient }\end{array}$ & $\begin{array}{l}\text { Standard deviation } \\
\text { of regression coefficient }\end{array}$ & t-distribution \\
\hline$a$ & 0.978606 & 0.02794 & 35.0251 \\
\hline$b$ & 0.672183 & 0.02101 & 31.9855 \\
\hline $\begin{array}{l}Z=1.8870783 \cdot 10^{-8} \\
M=46 \\
\alpha=0.05\end{array}$ & \multicolumn{2}{|c|}{$\begin{array}{r}R=0.989 \\
R_{k}=0.409 \\
t_{k}=2.018\end{array}$} & $\begin{array}{l}090.54 \\
3.21 \\
3.03 \%\end{array}$ \\
\hline
\end{tabular}

Table 3

List of parameters appearing in equation for average mechanical rate of penetration with a cogged bit $0.56 \mathrm{~m}$ in diameter in layers $\mathrm{W}_{2}$

\begin{tabular}{|c|c|c|c|}
\hline Dependent parameter & $\begin{array}{l}\text { Regression } \\
\text { coefficient }\end{array}$ & $\begin{array}{c}\text { Standard deviation } \\
\text { of regression coefficient }\end{array}$ & $\mathrm{t}$-distribution \\
\hline$a$ & 1.36043 & 0.050065 & 27.1732 \\
\hline$b$ & 0.587293 & 0.040222 & 14.6013 \\
\hline $\begin{array}{l}Z=3.51692 \cdot 10^{-10} \\
M=43 \\
\alpha=0.05\end{array}$ & \multicolumn{2}{|c|}{$\begin{aligned} R & =0.976 \\
R_{k} & =0.419 \\
t_{k} & =2.021\end{aligned}$} & $\begin{array}{l}24.548 \\
3.23 \\
4.85 \%\end{array}$ \\
\hline
\end{tabular}


Industrial tests were made to evaluate the efficiency of drilling large diameter intake wells with a cogged bit 0.56 in diameter, according to the presented model of average rate of penetration. When drilling with a rig Wirth $\mathrm{B} 3 \mathrm{~A}$, the following technological parameters were applied in view of the type of drilled layers:

- outer diameter of drill pipe

- weight of bit

- rotary speed of bit

- volumetric stream of drilling mud

- drilling mud flow rate inside drilling pipe

$$
\begin{array}{r}
0.145 \mathrm{~m}, \\
1.96-4.90 \cdot 10^{4} \mathrm{~N}, \\
0.5-1.5 \mathrm{~s}^{-1}, \\
0.077 \mathrm{~m}^{3} / \mathrm{s}, \\
4.3 \mathrm{~m} / \mathrm{s} .
\end{array}
$$

The average rates of penetration obtained during industrial tests with that bit were $6.94 \times 10^{-4}$ to $4.16 \times 10^{-4} \mathrm{~m} / \mathrm{s}$, which was higher than the values obtained so far by 143.11 to $189.22 \%$.

\section{CONCLUSIONS}

1. The rate of penetration of short sections in carbonate rocks with a cogged bit $0.56 \mathrm{~m}$ in diameter is best described by a power equation showing impact of weight on bit and rotational speed on rate of penetration.

2. The presented model of average rate of penetration for a cogged bit $0.56 \mathrm{~m}$ in diameter will considerably increase the efficiency of drilling large diameter intake wells in carbonate rocks in the Lublin area.

3. In industrial practice the selection of optimum mechanical parameters of drilling technology should account for limitations stemming from the weight of bit and rotational speed of the bit.

4. When drilling large diameter wells with cogged bits, additional restrictions connected with the technical characteristic of the rig and the string should be taken into account.

\section{REFERENCES}

[1] Aadnoy B.S.: Modern Wells Design. A.A. Balkema, Rotterdam, Netherlands, 1996.

[2] Besson A., Toutain P., Meany N.: Improved BHAs, bits optimize drilling performance. Drilling Contractors, vol. 49, nr 1, 1993.

[3] Cobb G.W.: Introduction to Design and Analysis of Experiments. Springer, New York 1998.

[4] Dobosz M.: Wspomagana komputerowo statystyczna analiza wyników badań. Akademicka Oficyna Wydawnicza EXIT, Warszawa 2001. 
[5] Gonet A.: Calculation of optimum time of drilling the hole with cutter bit. Archiwum Górnictwa, vol. 37, z. 3, 1992.

[6] Gonet A.: Optymalizacja mechanicznych parametrów technologii wiercenia otworów świdrami skrawajacymi. Przegląd Górniczy, nr 5, 1995.

[7] Greń J.: Statystyka matematyczna. Modele i zadania. Wydawnictwo Naukowe PWN, Warszawa 1999.

[8] Kleczkowski A.S. (Ed.): Mapa obszarów głównych zbiorników wód podziemnych (GZWP) w Polsce wymagających szczególnej ochrony, 1:500 000. Akademia Górniczo-Hutnicza, Kraków 1990.

[9] Krajewski S., Motyka J.: Model sieci hydraulicznej w skałach węlanowych w Polsce. Biuletyn Państwego Instytutu Geologicznego, 388, 1999, pp. 115-138.

[10] Macuda J.: Analysis of Efficiency of Drilling of Large-diameter Wells with a Profiled Wing Bit. Archives of Mining Sciences, vol. 57, no. 2, 2012, pp. 363-373.

[11] Miska S.: Identyfikacja procesu wiercenia narzędziami skrawającymi. Archiwum Górnictwa, vol. 2, z. 3, 1975, pp. 473-482.

[12] Nowicki Z. (Ed.): Charakterystyka geologiczna i hydrogeologiczna zweryfikowanych JCWPd. Raport z realizacji zadania Państwowej Służby Hydrogeologicznej, Zadanie 28, Państwowy Instytut Geologiczny - PIB, Krajowy Zarząd Gospodarki Wodnej, Warszawa 2009.

[13] Paczyński B., Sadurski A. (Eds.): Hydrogeologia regionalna Polski. Tom I. Wody słodkie. Państwowy Instytut Geologiczny, Warszawa 2007.

[14] Pawłowski A., Pawłowski L.: Zaopatrzenie $w$ wodę $w$ świetle zrównoważonego rozwoju. Gospodarka Wodna, nr 4, 2013, pp. 133-136.

[15] Perry P.B., Curry D.A., Kerridge J.D., Lawton J.: A Case Based Knowledge Repository for Drilling Optimization. IADC/SPE Asia Pacific Drilling Technology Conference and Exhibition, 13-15 September 2004, Kuala Lumpur, Malaysia.

[16] Stanisz A.: Przystępny kurs statystyki z zastosowaniem STATISTICA PL na przykładach z medycyny. Wydawnictwo StatSoft Polska, Kraków 2007.

[17] Wiłun Z.: Zarys geotechniki. Wydawnictwa Komunikacji i Łączności, Warszawa 2003.

[18] Wiśniowski R., Stryczek S., Skrzypaszek K.: Kierunki rozwoju badań nad reologia plynów wiertniczych. Wiertnictwo, Nafta, Gaz, t. 24, z. 1, 2007, pp. 595-607.

[19] Wiśniowski R.: Dobór typów świdrów gryzowych do rodzaju przewiercanych skat. Cz. 1. NTTB Nowoczesne Techniki i Technologie Bezwykopowe, nr 2, 1999, pp. 20-26.

[20] Wiśniowski R., Stęperski P.: Wpływ parametrów reologicznych modelu HerschelaBulkleya na wynoszenie zwiercin. Wiertnictwo, Nafta, Gaz, t. 25, z. 2, 2008, pp. 783-789. 